\title{
Monitoring and forecasting of intensive convective precipitation with the use of the mobile meteorological radar (MMR50)
}

\author{
David Šaur ${ }^{1 a}$ and Pavel Tomášek ${ }^{1}$ \\ ${ }^{1}$ Faculty of Applied Informatics, Tomas Bata University in Zlín, Namesti T.G.Masaryka 5555, 76001 Zlin, Czech Republic
}

\begin{abstract}
This paper is focused on current possibilities of the measurement and predictions of intense convective precipitation through the mobile meteorological radar (MMR50). This meteorological radar equipment is part of the Information, Notification and Warning system of the Zlin Region in the Czech Republic, which consists of information and communication infrastructure for dealing with extraordinary events. The first chapter describes basic principles of radar precipitation measurement, e.g. radar estimate of rainfall intensity and radar products. The second chapter presents a methodology of measuring and predicting of intense convective precipitation using the mobile meteorological radar (MMR50), including other possibilities of precipitation forecast as NWP models, aerological, satellite, station measurements, statistics of historical situations, the risk of flash floods on the degree of soils saturation and the possibility of observation of dangerous accompanying phenomena. The last chapter deals with the verification of the principles of radar measurements and forecasts in a case study on $24^{\text {th }}$ July 2015 . Torrential rainfall in a combination with hail and strong wind gusts caused heavy flooding in the central part of Zlin region, which caused considerable material damage. Timely and quality information about the current and future formation and development of intense convective precipitation is essential for flood prevention measures. Acquired findings and conclusions can be used for crisis management in case of a possible occurrence of flash floods.
\end{abstract}

\section{Introduction}

The Zlín Region is one of the regions of the Czech Republic, which have been strongly affected by the impacts of local flash floods in the past decade. Three extensive flooding caused by persistent and intensive precipitation occurred in 1997-2006 (145 billion of material damages and the death toll of 88). This type of flooding is a specific with large expanse of the affected area. In contrast, flash floods have occurred regularly since 2007 until present (35 billion in material damages and the death toll of 41). This type of flooding affects the area of the very small size in the order of several $\mathrm{km}^{2}$. Material damages are caused not only by torrential rainfall but also other hazardous atmospheric phenomena such as hail, strong wind gusts, tornadoes and atmospheric electrical discharges. Although, flash floods have not caused flood damage to the same extent as the second type of the flood, they occur at a substantially higher frequency.

In addition, current possibilities forecasting possibilities of flash floods probability are very limited. The forecasting of torrential rainfall is realized by NWP models and nowcasting systems. Both prediction methods achieve relatively low success rate, up to about $50 \%$. Consequently, the Zlin Region has decided to actively solve this problem by creating the Information, Notification and Warning System of the Zlin Region.
This system is formed by the backbone of information and communication infrastructure of the Zlin Region. The essence is its own internal network made of fiber optic cable, whose users are independent from the Internet and other external sources. The central unit is a server located on the regional managing workplace of the Crisis Staff of the Zlin Region. Information is distributed from this department to another 11 municipalities with extended powers. The main advantage is the efficient communication between the authorities of Crisis Management and the Integrated Rescue System of the Czech Republic before the occurrence and during extraordinary events [1].

Information, Notification and Warning System of the Zlin Region consist of many components, such as central dispatching, warning information systems, video conferencing systems, municipal camera surveillance systems, sensors and meteorological stations, chemical detection elements, substitute energy sources and the mobile meteorological radar (MMR50). This meteorological radar is a major tool intended for monitoring the current precipitation situation and very short-term forecasts for 30-60 minutes. The purpose of the device is to provide timely and relevant information on the weather situation, which may arise from a flash flood [2].

The main objective of this article is to describe the methodology of monitoring and forecasting of dangerous

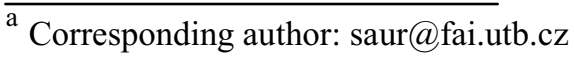


weather phenomena by using the MMR50 meteorological radar.

\section{Radar precipitation measurements}

The mobile meteorological radar (MMR50) is a device intended for:

- Precipitation clouds detection,

- The intensity of precipitation estimation and

- The 3D information obtaining about the distribution of precipitation in the atmosphere.

\subsection{Principle of radar precipitation measurement}

The mobile meteorological radar (MMR50) consists of an antenna, which generates a narrow beam of high-energy pulses. When the beam encounters a particle of cloud, it is partially absorbed and then dispersed in all directions. Scattered rays are captured by the antenna where are subsequently amplified and detected by the radar receiver. The receiver calculates power of rays and the time from the pulse. The analog signal is digitized and processed by the special software. The resulting information is displayed to end users in the form of an image with radar reflections on a map [3], [4], [5].

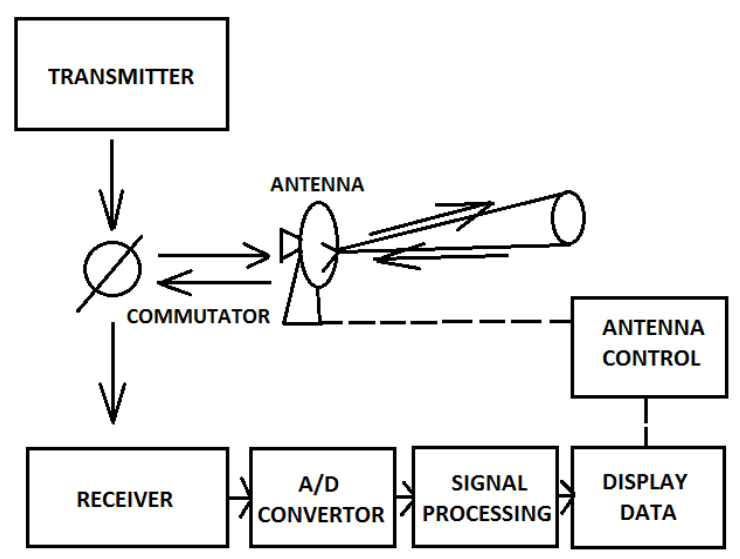

Figure 1. Scheme of the meteorological radar MMR50 [6].

The mobile meteorological radar (MMR50) also consists of other components such as radar units, elevation and azimuth drive including sensors, heating and cooling system, and power source part and the control computer [1].

Table 1. Parameters of the MMR50 meteorological radar [7].

\begin{tabular}{|c|c|}
\hline Parameters & Values \\
\hline $\begin{array}{c}\text { Operating } \\
\text { frequency }\end{array}$ & $\begin{array}{c}\text { X-band } \\
(9410 \\
\mathrm{MHz})\end{array}$ \\
\hline $\begin{array}{c}\text { Transmitter } \\
\text { Power Peak }\end{array}$ & $50 \mathrm{~kW}$ \\
\hline $\begin{array}{c}\text { Antenna } \\
\text { Elevation }\end{array}$ & $-1^{\circ}$ to $+90^{\circ}$ \\
\hline
\end{tabular}

\begin{tabular}{|c|c|}
\hline $\begin{array}{c}\text { Pulse } \\
\text { Repetition } \\
\text { Frequency }\end{array}$ & $500 \mathrm{~Hz}$ \\
\hline $\begin{array}{c}\text { Maximum } \\
\text { range }\end{array}$ & $100 \mathrm{~km}$ \\
\hline
\end{tabular}

As can be seen in Table 1, The mobile meteorological radar (MMR50) operates at X-band with a wavelength of $3 \mathrm{~cm}$. The advantage of this feature is higher detection sensitivity of intense precipitation but with a significantly higher attenuation, lower repetition frequency and maximum range than meteorological radars from the Czech Radar Network.

\subsection{Radar estimation of the rainfall intensity}

Fundamental radar parameter is the radar reflectivity. Radar reflectivity is the amount of energy reflected from precipitation of cloud particles, where $N$ (D) denotes the spectrum of particle sizes and $D_{i}$ represents the diameter of a droplet [3]:

$$
Z=\Sigma D_{i}^{6}=\int N(D) D^{6} d D
$$

Measured radar reflectivity is reported as $10 \log Z_{\mathrm{e}}$ $\left[\mathrm{mm}^{6} / \mathrm{m}^{3}\right]$ in the unit of $\mathrm{dBz}$.

Rainfall intensity $I$ is dependent on the radar reflectivity $Z$ determined using the Marshall-Palmer formula:

$$
Z=a I^{b}
$$

where $a$ and $b$ are experimentally determined constants ( $a$ $=200, b=1.6$ ). Rainfall intensity $I$ is calculated by the following formula [3], [4], [5]:

$$
I=10(Z-10 \log (a)) / 10 b \text {. }
$$

\begin{tabular}{|c|c|c|}
\hline $\mathrm{Z}[\mathrm{dBz}]$ & $\mathbf{I}[\mathbf{m m} / \mathbf{h r}]$ & Meteorological targets \\
\hline 7 & 0,1 & Weak rain \\
\hline 23 & 1 & Moderate rain \\
\hline 39 & 10 & Intensive rain \\
\hline 48 & 37 & $\begin{array}{c}\text { Intensive convective } \\
\text { precipitation }\end{array}$ \\
\hline 52 & 65 & Torrential rainfall \\
\hline 56 & 100 & Intensive torrential rainfall \\
\hline 60 & 200 & Hail, tornadoes \\
\hline
\end{tabular}

Table 2. The exponential dependence of radar reflectivity and intensity of precipitation [6].

Table 2 shows that the radar reflectivity $Z$ is changing exponentially dependent on the change of rainfall intensity. 


\subsection{D information of the MMR50 meteorological radar}

The mobile meteorological radar (MMR50) processes the input data into materials for analyzing and forecasting meteorological radar maps, and the subsequent distribution of documents to the Information, Notification and Warning System of the Zlin Region

3D radar information consists of the original volume of the radar data stored in Spherical coordinates which are converted into Cartesian coordinates. The result is product of radar reflectivity:

-PPI (Plan Position Indicator) is the field of radar reflectivity measured at various elevation angles. The algorithm is based on bilinear interpolation for each pixel separately.

-CAPPI (Constant Altitude Plan Position Indicator) the field of radar reflectivity calculated for a given altitude.

-ColumnMax (Composite Reflexivity) is the maximum radar reflectivity in a vertical column of the atmosphere.

-RHI (Range Height Indicator) is a vertical sectional view of the atmosphere where the main parameter is the azimuth. RHI algorithm is calculated as with the PPI.

-Max Z the maximum field of radar reflectivity with side projections representing a vertical column of the atmosphere.

-ECHOTOPS provides information on cloud altitude, with a maximum radar reflectivity.

-VIL (Vertically Integrated Liquid) is a vertically integrated liquid water content determined by assuming the Marshall-Palmer distribution; VIL value is determined by the following formula:

$$
V I L=3,44 \cdot 10^{-6} \int_{h z}^{h t} Z^{4 / 7} d h,
$$

where Z [mm6.m-3] radar reflectivity, hz [m] height of the cloud base and ht [m] is the height of the cloud top. Summation over different levels of PPI is performed each surface element [3], [7].

These radar products (results) are used to specify the radar information in real time. The main objective is to obtain current information on the rainfall intensity and a probable occurrence of dangerous atmospheric phenomena.

\section{Methodology of the measurement and forecasting of intensive convection precipitation}

Radar results of the mobile meteorological radar (MMR50) provide us with information about the current state of the occurrence of precipitation in the atmosphere. One of the software components is an application Nowcast TITAN that provides predictive information about the intensity of precipitation equal or higher than $37 \mathrm{~mm} / \mathrm{hr}$. However, this predictive information is insufficient to assess the future occurrence of flash floods. Each meteorologist must have information on the conditions of air masses, satellite, aerological, station and other data.

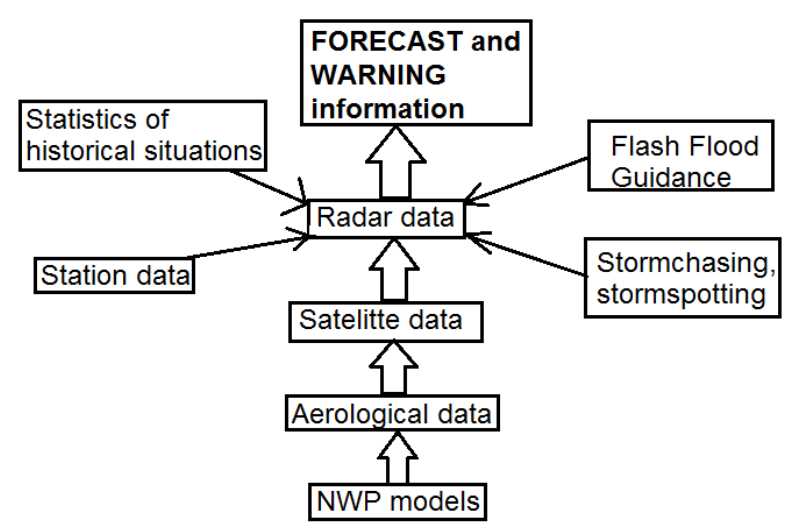

Figure 2. Scheme of the forecast and warning of the flash flood.

Complex intense convective precipitation forecast includes data from:

-NWP models an aerological radiosonde (indices of convection, meteorological elements).

-Satellite data (Infra-Red image and IR image in the thermal spectrum)

-Radar data (outputs of the 6 radar products, statistics of historical situations, station data, the degree of the soil saturation and data from observations of thunderstorms).

\subsection{Radar precipitation measurement}

Analysis of the current rainfall situation contains the following information:

Table 3. Radar measurement intensive convective precipitation.

\begin{tabular}{|c|c|c|}
\hline $\begin{array}{c}\text { Radar } \\
\text { products }\end{array}$ & $\begin{array}{c}\text { Limits of } \\
\text { measurement }\end{array}$ & $\begin{array}{c}\text { Dangerous } \\
\text { atmospheric } \\
\text { phenomena }\end{array}$ \\
\hline $\begin{array}{c}\text { ColumnMax, } \\
\text { Max Z }\end{array}$ & $52 \mathrm{dBz}$ & $\begin{array}{c}\text { Moderate } \\
\text { torrential } \\
\text { rainfall }\end{array}$ \\
\hline & $56 \mathrm{dBz}$ & $\begin{array}{c}\text { Intensive } \\
\text { torrential } \\
\text { rainfall }\end{array}$ \\
\hline CAPPI & $2 \mathrm{~km}$ & $\begin{array}{c}\text { Hail, } \\
\text { tornadoes }\end{array}$ \\
\hline RHI & $2-4 \mathrm{~km}$ & $\begin{array}{c}\text { Torrential } \\
\text { rainfall }\end{array}$ \\
\hline ECHOTOP & above $10 \mathrm{~km}$ & $\begin{array}{c}\text { Torrential } \\
\text { rainfall, hail, } \\
\text { tornadoes }\end{array}$ \\
\hline VIL & $\begin{array}{c}\text { above } 30 \\
\mathrm{~kg} / \mathrm{m}^{2}\end{array}$ & $\begin{array}{c}\text { Torrential } \\
\text { rainfall, hail, }\end{array}$ \\
\hline
\end{tabular}

Probability prediction of the occurrence of dangerous accompanying phenomena must be combined with the outputs of NWP models, aerological, satellite and station measurements. 


\subsection{Very short-time forecast via MMR50 meteorological radar}

The very short-term forecast is performed through the application of Nowcast TITAN. The principle of this system is simple. The algorithm marked on the map, such precipitation fields that have reached the radar reflectivity $(\mathrm{Z}=48 \mathrm{dBz})$, determines the direction of movement based on previous precipitation radar outputs and the red arrow indicates where the rainfall field will move during 30-60 minutes [1].

Comprehensive forecasting of flash floods is supplemented by information from:

-Statistics of historical weather situations.

-Degree of saturation of soils obtained from the Flash

Flood Guidance.

-Observations of thunderstorms (Stormchasing and Stormspotting).

Statistics of historical weather events are intended to supplement the resulting predictions. The main selection criteria of historical weather situations is the direction of movement of precipitation (wind direction at $700 \mathrm{hPa}$ ), the synoptic situation and significant meteorological parameters (temperature, relative humidity at 2 meters above ground, wind direction and wind speed of $10 \mathrm{~m}$ above ground).

The degree of soil saturation is analyzed from the Flash Flood Guidance and demonstrates the probability of occurrence of flash floods by the permeability of the soil surface.

Observations from the terrain thunderstorms are supplementary information to nowcasting which can detect and confirm the presence of dangerous accompanying phenomena. Simultaneously, the purpose of the data is control and verification of radar precipitation measurements.

\section{Case study on 24.7.2015}

The methodology of measurements and predictions using the mobile meteorological radar (MMR50) was verified on a case study dated July 24, 2015. The central part of the Zlin Region was hit by local flash floods accompanied by hail and strong wind gusts.

The forecast of the weather situation was very complicated. Czech Hydrometeorological Institute did not deliver predictive warning information on the occurrence of the strong thunderstorms for this region.

The triggering mechanism of intensive convective precipitation was cold front on the western Slovakia, which had a tendency to go back to the east of the Czech Republic.

\subsection{Outputs of radar precipitation measurement}

Formation and development of intense convective precipitation were demonstrated at various radar products as ColumnMax, CAPPI $2 \mathrm{~km}$, Max Z, Range Height Indicator (RHI), ECHOTOP and Vertically Integrated Liquid (VIL) in real time between 17: 18-18: 13. These radar results show certain qualities and character of intensive convective precipitation clouds.

\subsubsection{Radar products ColumnMax and CAPPI $2 \mathrm{~km}$}

Column Max is radar product which provides information about the maximum intensity of precipitation in the vertical column of the atmosphere. However, this output does not inform us about the current state of rainfall, but that a certain level of atmospheric precipitation occurs with the maximal intensity. Hence, the probable occurrence of rainfall is measured using CAPPI $2 \mathrm{~km}$.

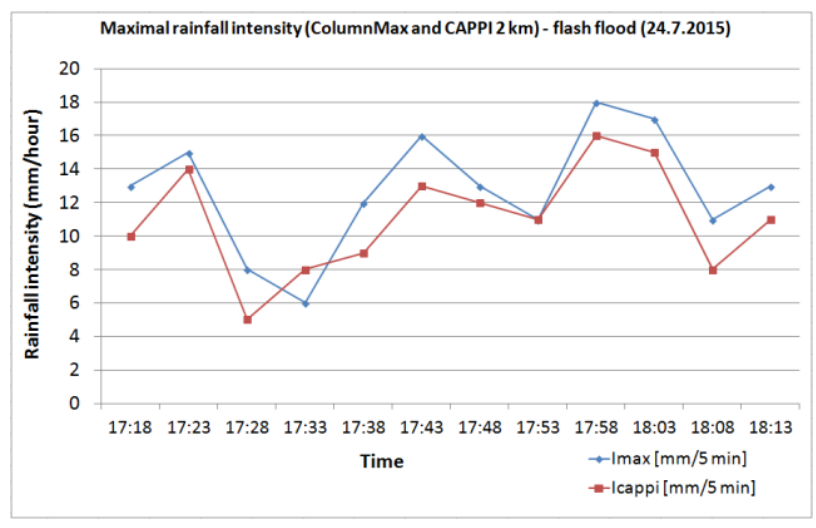

Figure 3. The current maximal intensity of precipitation measured by means of products Column Max and CAPPI $2 \mathrm{~km}$.

Rainfall in $\mathrm{mm} / 5$ minutes is calculated from hourly precipitation intensity, divided by 12 . Hour period had three peaks with the most intense rainfall. Rainfall intensity by product CAPPI $2 \mathrm{~km}$ achieved lower values than in ColumnMax, which determines the maximum intensity of precipitation in the whole atmosphere.

\subsubsection{Radar product Max Z}

Radar product Max Z contains information about the maximal intensity of precipitation in the column as ColumnMax and in addition horizontal and vertical distribution of rainfall intensity in different height levels.

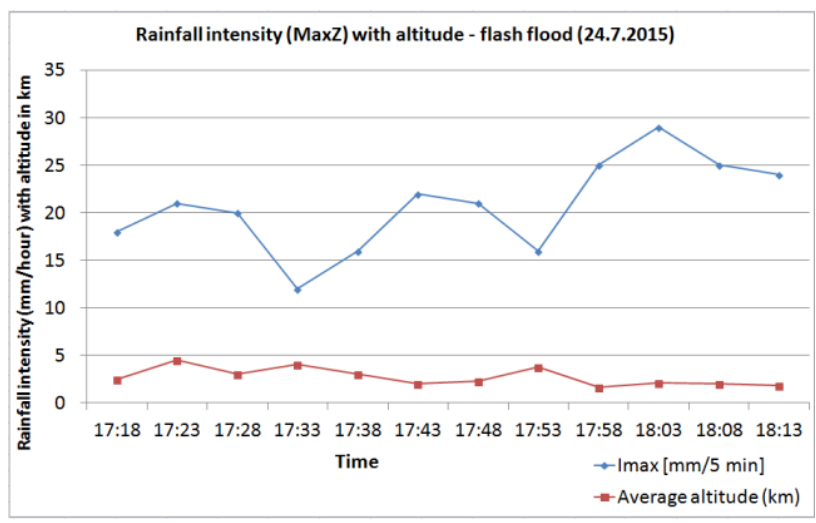

Figure 4. The current maximal rainfall intesity in different height levels (radar product Max Z).

Formation and development of convective precipitation clouds was clearly demonstrated by the outputs of the product Max Z. Intense convective 
precipitation occurred at the altitude of $3-5 \mathrm{~km}$ in the initial stages of development of convective storms; the mature stage in the levels of $2-4 \mathrm{~km}$ and the dissipating stage under $2 \mathrm{~km}$. The most intense rainfall occurred mainly in the mature and dissipating stage of convective storms.

\subsubsection{Radar product Range Height Indicator (RHI)}

Range Height Indicator RHI gives information about the vertical and horizontal spatial distribution of rainfall intensity in the azimuth. The main purpose is to detect the area of Bounded Weak Echo Region (BWER) and HOOK Echo at an altitude of 2-4 km, which indicates the presence of supercell storms accompanied by tornadoes

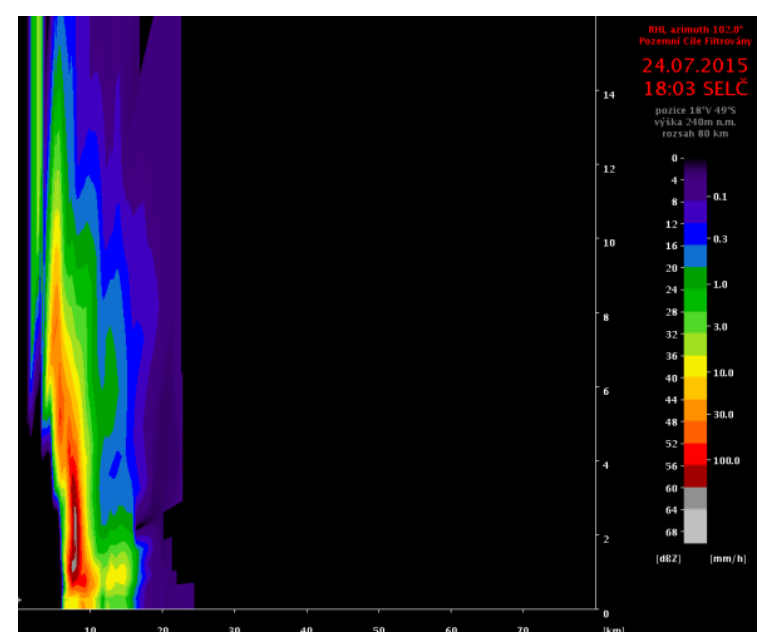

Figure 5. Vertical and horizontal distribution of rainfall intensity in the azimuth $102^{\circ}$ (radar product RHI).

Figure 5 illustrates the distribution of rainfall intensity in the process of dissipating of convective storms. The most intensive reflections in the form of hail occurred at the level of $2 \mathrm{~km}$ and then below this level.

\subsubsection{Radar product ECHOTOP}

ECHOTOP radar product provides additional information about the occurrence of the maximum rainfall intensity at the highest altitude.

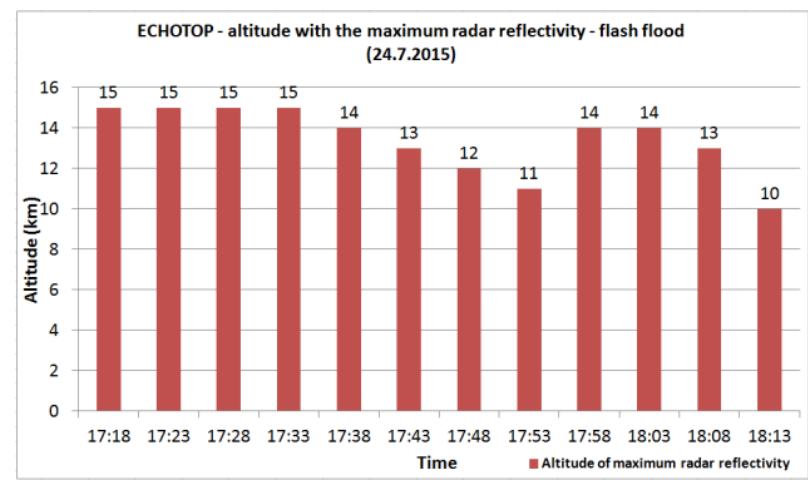

Figure 6. The height of the maximum rainfall intensity (radar product ECHOTOP).
Figure 6 shows that rainfall maximum intensity was present at an altitude of $15 \mathrm{~km}$ in the initial development of convective cells. Height occurrence of intense precipitation has gradually decreased $(14-10 \mathrm{~km})$ due to loss precipitation in the process of dissipating of convective storms.

\subsubsection{Radar product Vertically Integrated Liquid VIL}

Radar product VIL gives information about the amount of liquid water contained in the cloud in $\mathrm{kg}$ per $\mathrm{m}^{2}$. This product is very important for the prediction of torrential rainfall which can cause the flash flood.

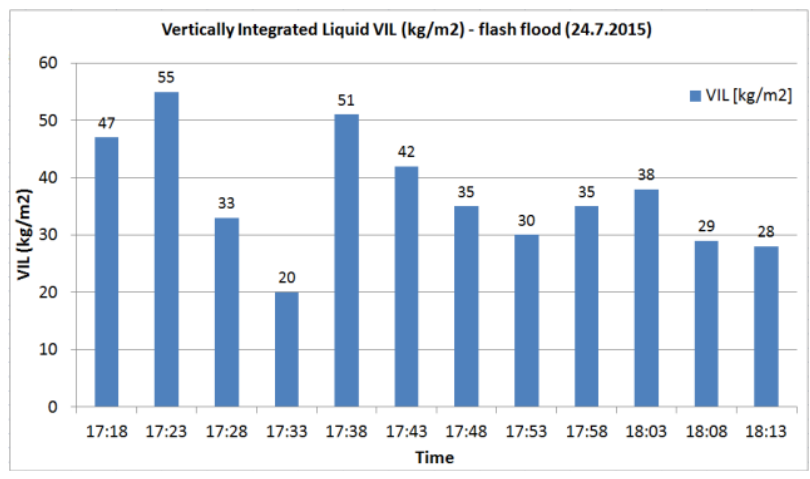

Figure 7. The quantity of liquid water contained in the convective precipitation clouds.

Figure 7 demonstrates the greatest amount of liquid water which was presented in convective precipitation clouds in the initial stage of development and the mature stage of convective storms. Torrential rainfall was measured in the district Vsetin and Zlin between 17 and 18 hours. Station precipitation measurements corresponded with radar outputs.

\subsection{Outputs of forecasting precipitation using Nowcast TITAN}

Very short-term forecast was implemented by software Nowcast TITAN. The output of was a graphical information about the current and future state of intense convective precipitation for 30-60 minutes in advance. Nowcast TITAN determines the area of municipalities with extended powers of the Zlin Region, for which it was calculated the forecast of precipitation locations and the direction of movement precipitation:

Table 4. Forecast precipitation of the Nowcast TITAN.

\begin{tabular}{|c|c|c|c|}
\hline $\begin{array}{c}\text { Time } \\
\text { period }\end{array}$ & $\begin{array}{c}\text { Measured } \\
\text { precipitation } \\
\text { in locations }\end{array}$ & $\begin{array}{c}\text { Predicted } \\
\text { precipitation } \\
\text { in locations }\end{array}$ & $\begin{array}{c}\text { Direction of } \\
\text { precipitation } \\
\text { motion }\end{array}$ \\
\hline $\begin{array}{c}\text { 17:18- } \\
17: 33\end{array}$ & $\begin{array}{c}\text { Vsetín, } \\
\text { Rožnov, } \\
\text { Vizovice }\end{array}$ & $\begin{array}{c}\text { Walachín } \\
\text { Meziříćí, } \\
\text { Bystřice }\end{array}$ & $\begin{array}{c}\text { Southeast } \\
\text { (SE) }\end{array}$ \\
\hline $\begin{array}{c}\text { Vs:38- } \\
17: 48\end{array}$ & $\begin{array}{c}\text { Vsetín, } \\
\text { Vizovice, Zlín }\end{array}$ & $\begin{array}{c}\text { Walachín } \\
\text { Meziříćí, Zlín }\end{array}$ & $\begin{array}{c}\text { Southeast } \\
\text { (SE) }\end{array}$ \\
\hline $\begin{array}{c}17: 53- \\
18: 18\end{array}$ & $\begin{array}{c}\text { Vsetín, } \\
\text { Bystřice, Zlín }\end{array}$ & $\begin{array}{c}\text { Bystřice, Zlín, } \\
\text { Holešov }\end{array}$ & East (E) \\
\hline
\end{tabular}




\subsection{Other forecasting outputs}

Outputs of the Nowcast TITAN were supplemented by other information, which is very important for predicting probability of occurrence of flash floods:

-NWP models predict rainfall intensity $30-50 \mathrm{~mm} /$ $\mathrm{hr}$ for the phenomenon of "Strong thunderstorms".

-Satellite measurements were measured maximum temperature cloud top $-60^{\circ} \mathrm{C}$ which is typical for vertically developed convective clouds.

-The anticipated rate of precipitation was confirmed by statistics of historical situations in the areas of Vsetin, Vizovice, Zlín and Bystřice in the days 7.11 and 8.07.2011.

-The highest degree of soil saturation (the highest risk of flash floods) was computed from the area Roznov, Vsetin, Zlín and Bystrice.

-Amateur meteorologists have confirmed the occurrence of thunderstorms accompanied by torrential rainfall and hailstorm in the municipalities Fryšták, Zlín-Štípa, Lukov, and Hrobice. Strong wind gusts were seen in Zlín-Malenovice which caused material damage to the roofs of houses.

\section{Conclusion}

The aim of the article was to provide information about current possibilities of monitoring and predictions of intense convective precipitation in the Zlin Region, Czech Republic. Principles of the methodology of measurements and predictions via the mobile meteorological radar (MMR50) were verified on a case study of the July 24, 2015 when the Zlin Region was hit by flash floods.

The most intense precipitation was predicted for area district the Vsetín, Zlin and Bystrice using the software Nowcast TITAN, which is part of the meteorological radar equipment. Convective precipitation over $30 \mathrm{~mm} /$ $\mathrm{h}$ was measured in the Vsetín district (ground meteorological station Huslenky $33.8 \mathrm{~mm}$ and Hoštálková $33.1 \mathrm{~mm}$ ) and Zlin (ground meteorological station Zlin-Stipa $42.8 \mathrm{~mm}$ ). Station measurements showed the $80 \%$ success rate in predictions of locations of intense convective precipitation. In addition, the occurrence of hailstorms and strong wind gusts was confirmed by observations of amateur meteorologists in the central part of the Zlin Region. These dangerous atmospheric phenomena caused material losses of tens of millions of crowns.

Future research will concentrate on the optimization of limits setting for individual radar products, the expansion of the database of historical weather events statistics and observation networks of amateur meteorologists. The main objective will be to ensure timely and quality information on the current and future state of intense convective precipitation, which may cause flash floods.

\section{Acknowledgement}

This work was supported by the Internal Grant Agency of Tomas Bata University under the project No. IGA/ FAI/ 2016/023 "Optimization of the System of Convective Precipitation Forecasts for Increase its Success Rate".

\section{References}

1. Information, Notification and Warning System of the Zlín Region, Integrated project, Zlín Region. 2012 Avalaible at: http://www.kr-zlinsky.cz/-informacnivyrozumivaci-a-varovaci-system-zlinskeho-krajeintegrovany-projekt-cl-1392.html

2. IVVS Zlín Region - Information, Notification and Warning System" Avalaible at: http://www.colsys.cz/novinky/detail/ivvs-zlinskehokraje.htm

3. D. Rezacova, et al. Physics of clouds and precipitation. Prague: Academia, 2007. 574 pp. with. Fig.Gerstner; sv. 2. ISBN 978-80-200-1505-1.

4. Czech Hydrometeorological Institute Radar network CHMI. 2010-2011 Available at: http:// http://www.chmi.cz/files/portal/docs/meteo/rad/info czrad/index.html

5. J. Kracmar, Meteorological radars. Czech Hydrometeorological Institute. 1997-2011. Available: $\quad \mathrm{http} / /$ http://www.chmi.cz/files/portal/docs/meteo/rad/info_ radar/index.html

6. D. Saur, R. Zak, J. Svejda. 19. International Conference on Systems (CSCC '15), Special Session: Informatics in Control Theory and its Applications - Control Applications. Recent Advances in Systems. Zakynthos Island, Greece, July 16-20, 2015, s. 280-285. ISBN: 978-1-61804321-4. ISSN: 1790-5117.

7. D. Saur, S. Plsek. International Journal of Circuits, Systems and Signal Processing. 2014, ISSN: 19984464. Avalaible http://www.naun.org/main/NAUN/ circuitssystemssignal/2014/a192005-045.pdf 